\title{
OPTIMIZATION OF FERMENTATION CONDITIONS FOR CELL ENVELOPE PROTEINASE PRODUCED BY LACTOBACILLUS PLANTARUM LP69
}

\author{
- Research paper - \\ Chi ZHANG ${ }^{*}$, He CHEN*, Ni LEI*, Guanli DU**,Xiangyun LI**, Zemin LIU**, Jili CAO ${ }^{1 * * *}$ \\ *School of Food and Biological Engineering, Shaanxi University of Science \& Technology, Xi'an, \\ 710021, China; \\ **Department of Research and Development, Xi'an Xiyangyang Biological Technology Co., Ltd., \\ $X i$ 'an, 710028, China \\ *** Xi'an Oriental Dairy Co., Ltd., Xi'an, 710027, China
}

\begin{abstract}
Cell-envelope proteinases (CEPs) can hydrolyze casein into functional peptides, which is beneficial to the health of the host. The single factor experiment screened out that the optimal conditions for CEP production by Lactobacillus plantarum $L P 69$ were $37^{\circ} \mathrm{C}, 20 \mathrm{~h}$, initial $\mathrm{pH}$ of 7 , and optimal inoculation amount of $5 \%$. The best conditions for this experiment were obtained by orthogonal experiment: time $22 \mathrm{~h}$, temperature $39^{\circ} \mathrm{C}$, initial $\mathrm{pH}$ value of 6 , and inoculation amount of $5 \%$. Under this culture condition, the target protease activity of Lactobacillus plantarum LP69 reached $22.31 \pm 0.82 \mathrm{U} / \mathrm{mL}$, the protein content was $19.07 \pm 0.36 \mathrm{mg} / \mathrm{mL}$, and the specific activity was $1.17 \pm 0.06 \mathrm{U} / \mathrm{mg}$. The specific activity significantly increased by $15.8 \%$ compared with the control $(p<0.05)$.
\end{abstract}

Keywords: Lactobacillus plantarum; cell-envelope proteinases; fermentation optimization, Orthogonal experiment

\section{INTRODUCTION}

Lactic acid bacteria (LAB) is a general term for bacteria that can use fermentable carbohydrates to large amounts of lactic acid (Widyastuti et al., 2014; Liu et al., 2001; Zhao et al.,2019). This type of bacteria is extremely widespread in nature. They have significant academic value in theory and can be used as ideal materials for classification, biochemistry, genetics, molecular biology and genetic engineering research. In addition, it also has high application value in some fields closely related to human life,such as food and medicine industry (Evivie et al., 2017; Roobab et al., 2020). Some lactic acid bacteria, also known as probiotics, can help digestion and contribute to the health of the human gastrointestinal tract (Rolfe,2000; Tatsuya et al., 2015; Shu et al., 2016). Lactobacillus plantarum is a very widespread lactic acid bacterium. This bacterium is the native bacterium of the human intestinal tract and has a variety of probiotic functi-

Received: 25.02.2021

Accepted in revised form: 10.05 .2021 ons, including improving intestinal flora disorders and inhibiting intestinal infections. (Siezen et al., 2019; Georgieva et al., 2009)

The cell envelope proteinases (CEP), which exist on the cell wall, is a special type of proteolytic enzymes obtained from lactic acid bacteria. Protein can be hydrolyzed by CEPs into peptides of different sizes and some free amino acids to fit the growth of bacteria. Some of these peptides have certain biological activities, such as anti-oxidation, lowering blood pressure, and immune regulation. (Agyei et al., 2010; Christos et al., 2007) Past studies by our group have shown that the products of goat milk hydrolyzed by CEPs of Lactobacillus plantarum LP69 have strong antioxidant activity and angiotensin-I-converting enzyme (ACE)inhibitory activity (Chen et al., 2012; Chen et al., 2015). Therefore, it is necessary to study the production of CEP by Lactobacillus plantarum. Most of the existing researches are about the separation, purification and characteristics of CEP produced by some lactic acid bacteria (Chen et al.,

${ }^{1}$ Corresponding authors. E-Mail address: xiandfcj1@gmail.com 
2018; Laloi et al., 1991; Scolari et al.,2006). The production of CEP by lactic acid bacteria is not only affected by the composition of the medium, but also related to temperature and $\mathrm{pH}$. These fermentation parameters may affect the production and activity of CEP (Espeche et al.,2009). Samartsev et al. (2000) found that $\mathrm{pH}$ and medium composition had an important effect on the cell wall protease produced by Bifidobacterium adolescentis 94-BIM. Ren et al.

\section{MATERIALS AND METHODS}

\section{Microbial strains and media}

The School of Food and Biological Engineering, Shaanxi University of Science and Technology provided Lactobacillus plantarum LP69. The strain was cultured three generations in MRS broth medium at $37^{\circ} \mathrm{C}$ for $22 \mathrm{~h}$. Hopebiol Technology Co., Ltd. (Tianjin, China) provided Man Rogosa Sharpe (MRS) broth. All media were sterilized at $121^{\circ} \mathrm{C}$ for 15 minutes.

\section{Obtaining of crude CEPs}

After centrifugation at $4{ }^{\circ} \mathrm{C}$ and $4500 \mathrm{rpm}$ for $20 \mathrm{~min}$, washed the precipitate 3 times with $50 \mathrm{mM}$ TrisHCL buffer solution ( $\mathrm{pH} 7.8$ ) including $30 \mathrm{mM} \mathrm{Ca}^{2+}$. The precipitate was the bacterial cell. Poured the mixed solution ( $\mathrm{pH} 7.0$ ) containing $50 \mathrm{mM}$ TrisHCL buffer solution and $50 \mathrm{mM}$ EDTA-Na 2 into the sediment, stirred thoroughly, and cultured at $37^{\circ} \mathrm{C}$ for $1 \mathrm{~h}$. Centrifuged for 20 minutes at $4^{\circ} \mathrm{C}$, $4500 \mathrm{r} / \mathrm{min}$, and the supernatant was the crude enzyme solution of CEP.

\section{Fermentation conditions}

The effects of culture time $(16,18,20,22,24 \mathrm{~h}$, culture temperature $\left(33,35,37,39,41^{\circ} \mathrm{C}\right.$, initial $\mathrm{pH}$ value $(5,6,7,8,9)$ and inoculum amount $(1,3,5$, $7,9 \%$ on the protease activity, content and specific activity were investigated through single factor experiments, and the $\mathrm{pH}$ and $\mathrm{OD}_{600}$ values of the samples were measured. Then collected the bacteria, extracted the CEP protease, determined the enzyme activity, protein content, and calculated the specific activity to initially determine the optimal fermentation conditions. Orthogonal experiments were then carried out to determine the final optimization plan.
(2014) optimized the optimal fermentation conditions for cell-envelope protease production by Lactobacillus acidophilus JQ-1. Pang et al. (2017) found the best fermentation conditions for protease production by Lactobacillus helveticus through experiments, which improved the enzyme activity. However, there are still few related documents on the optimization of fermentation factor for the production of CEP by Lactobacillus plantarum.

\section{Culture pH and growth of Lactobacillus plantarum LP69 analysis}

Used a $\mathrm{pH}$ meter (PHS-3C) to record the $\mathrm{pH}$ value. The uninoculated culture medium was used as a control group, and the absorbance $\left(\mathrm{OD}_{600}\right.$ value) of the culture solution was recorded at a wavelength of $600 \mathrm{~nm}$ using a visible spectrophotometer SP756PC.

\section{Determination of protease activity}

According to previous studies, the Folin method was used for the determination of protease activity (Agyei et al., 2015).

\section{Protein determination}

Proteins content was estimated by Bradford method (Bradford, 1976) and bovine serum albumin was used as a standard.

\section{Determination of specific activity}

Specific activity is the enzyme activity per mg of enzyme protein, and the formula can be expressed as (Ngo et al., 2008):

Specific activity $(\mathrm{U} / \mathrm{mg})=\frac{\text { Total enzyme activity }(\mathrm{U})}{\text { Total protein }(\mathrm{mg})}$

\section{Data analysis and processing}

Each experiment was repeated three times and the average value was taken. Used the Origin 9 software package and Microsoft Excel 2010 to process the data. SPSS 19.0 statistical software was used for ttest calculation, and $\mathrm{P}<0.05$ was considered statistically significant. 


\section{RESULTS AND DISCUSSION}

\section{Effect of fermentation time on CEP produced by} Lactobacillus plantarum LP69

Keep other culture conditions (temperature $37^{\circ} \mathrm{C}$, inoculation amount 5\%, initial $\mathrm{pH} 7$, etc.) unchanged, when cultured for 16, 18, 20, 22 and 24 hours, samples were taken to determine the $\mathrm{OD}_{600}$ value and $\mathrm{pH}$ value, and the cell-envelope protease was extracted. Determined its enzyme activity and protein content to calculate the specific activity. The results are shown in Figure 1. Different culture times have an effect on the cell-envelope protease activity and the growth of LP69. When the culture time was gradually increased from $16 \mathrm{~h}$ to $20 \mathrm{~h}$, the enzyme activity, protein content and specific activity all had an upward trend. When the cultivation time continued to increase, the enzyme activity, protein content, and specific activity began to decrease. It may be due to long-term growth, a large number of LP69 growth and reproduction consumed nutrients in the early stage, resulting in the later period due to nutrient deficiency, which slowed down the reproduction of the bacterial species, and the corresponding enzyme activity was also reduced. .In addition, the $\mathrm{OD}$ and $\mathrm{pH}$ value also reached the maximum value at $20 \mathrm{~h}$, indicating that the growth and metabolism of LP69 was better at 20h. Therefore, long-term cultivation is not conducive to bacterial development and reproduction, and will lead to the decrease of the cell-envelope protease activity. Therefore, based on the test results, the culture time was selected as $20 \mathrm{~h}$.

\section{Effect of fermentation temperature on CEP produced by Lactobacillus plantarum LP69}

The selected culture time was $20 \mathrm{~h}$, the inoculum was $5 \%$, the initial $\mathrm{pH}$ was 7 , and the activated bacteria were respectively connected to the optimized culture at the culture temperature of 33, $35,37,39,41^{\circ} \mathrm{C}$. After culturing, samples were taken to determine the $\mathrm{OD}_{600}$ value and $\mathrm{pH}$ value, and the cell-envelope protease was extracted to measure the enzyme activity and the protein content to calculate the specific activity. Results are given in Figure 2.
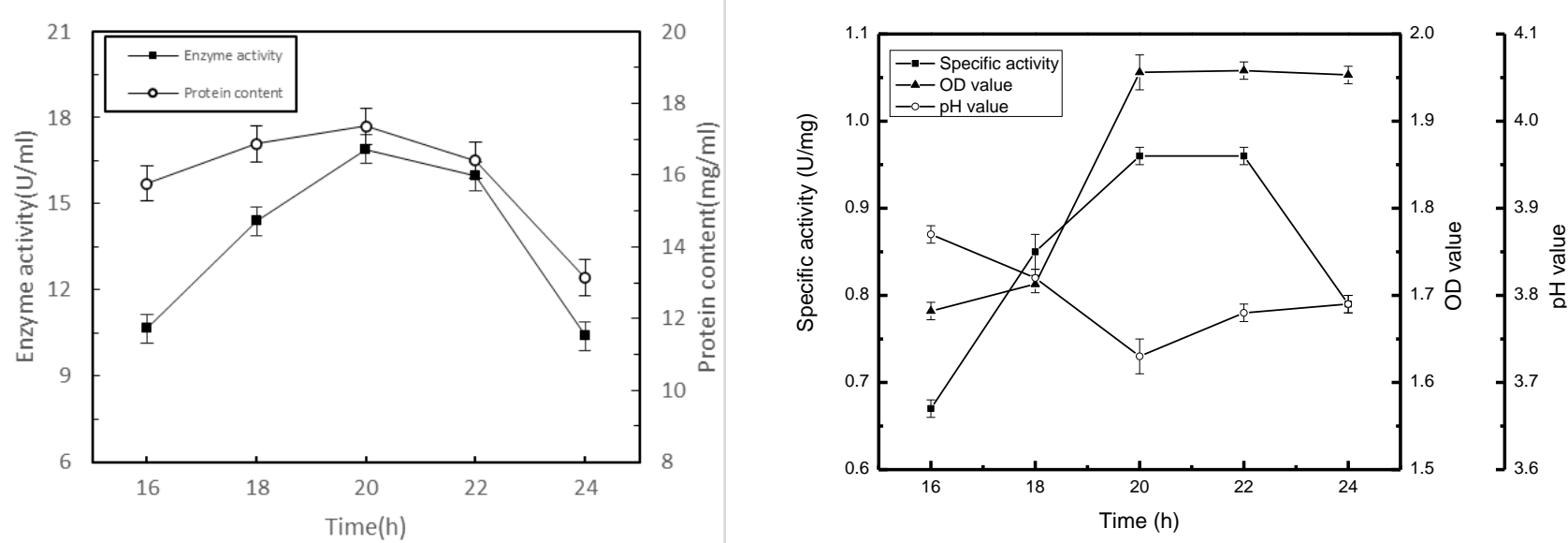

Figure 1. The effect of fermentation time on CEP produced by Lactobacillus plantarum LP69
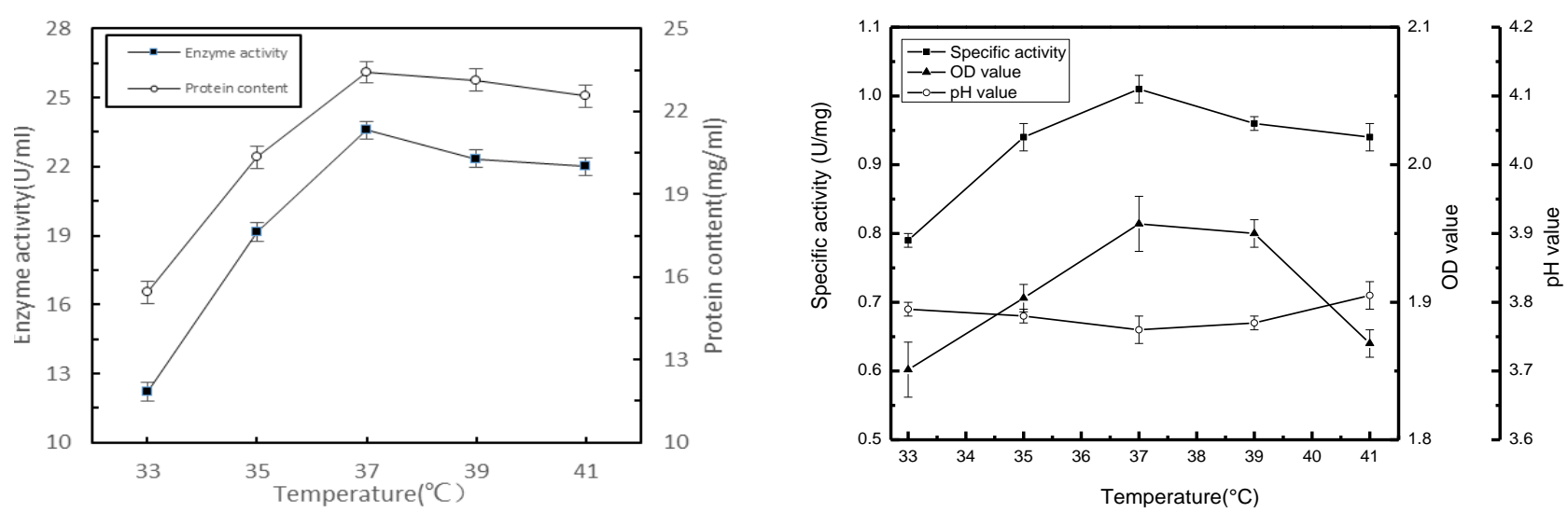

Figure 2. The effect of fermentation temperature on CEP produced by Lactobacillus plantarum LP69 
The enzyme activity and protein content gradually increase with the increase of temperature at the beginning, and reach the maximum values of 23.58 $\mathrm{U} / \mathrm{mL}$ and $23.42 \mathrm{mg} / \mathrm{mL}$ at $37^{\circ} \mathrm{C}$ (Figure 2). Then, with the increase of temperature, the protein activity and the protein content gradually decreased.The change trend of specific activity was roughly the same as that of enzyme activity, with a maximum value of 1.01 at $37^{\circ} \mathrm{C}$. The OD value and $\mathrm{pH}$ value also achieved a maximum value of 1.96 and a minimum value of 3.76 at $37^{\circ} \mathrm{C}$. The $\mathrm{OD}$ value decreased at $39^{\circ} \mathrm{C}$ and $41^{\circ} \mathrm{C}$, indicating that too high temperature is not conducive to the development of bacteria. Therefore, the temperature of $L$. plantarum LP69 was determined to be $37^{\circ} \mathrm{C}$.

\section{Effect of initial pH on CEP produced by Lactobacillus plantarum LP69}

The growth of bacteria has its own optimal $\mathrm{pH}$. During the growth of Lactobacillus plantarum LP69, lactic acid is produced due to sugar metabolism, which makes the hydrogen ion concentration in the medium too high. If the hydrogen ion concentration exceeds the adaptation range of lactic acid bacteria, the growth of lactic acid bacteria will be inhibited. As time goes by, lactic acid accumulates, and the inhibitory effect will be more significant. Therefore, providing a suitable $\mathrm{pH}$ for the medium in the early stage of bacterial growth is very beneficial to the growth of lactic acid bacteria, and too high or too low will have an adverse effect on the lactic acid bacteria.

Adjusted the initial $\mathrm{pH}$ of the optimized medium with $1 \mathrm{~mol} / \mathrm{L} \mathrm{NaOH}$ or $\mathrm{HCL}$ to $5,6,7,8,9$ respectively, and other culture conditions remained unchanged (temperature $37^{\circ} \mathrm{C}$, inoculation volume $5 \%$, time $20 \mathrm{~h}$ ). After being cultivated, $\mathrm{OD}_{600}$ value, $\mathrm{pH}$ value, enzyme activity, protein content were measured and calculated the specific activity. When the initial $\mathrm{pH}$ value of the medium was gradually increased from 5 to 9 , the enzyme activity, protein content and specific activity had roughly the same changing trend, all of which increase first and then decrease, and are obtained at $\mathrm{pH}=7.0$ The maximum value, in addition, the $\mathrm{OD}_{600}$ value was also the highest and the $\mathrm{pH}$ value was the lowest at this time, so the initial pH value was 7 (Figure 3).

\section{Effect of inoculation amount on CEP produced by Lactobacillus plantarum LP69}

The selected culture time was $20 \mathrm{~h}$, the culture temperature was $37^{\circ} \mathrm{C}$, the initial $\mathrm{pH}$ value was 7 , and the activated bacteria were connected to the optimized inoculum at the volume ratio of $1,3,5,7$, and $9 \%$. In the culture medium, samples were taken to determine the $\mathrm{OD}_{600}$ value and $\mathrm{pH}$ value after culture, and the cell-envelope protease was extracted to measure the enzyme activity and the protein content to calculate the specific activity. Results are given in Figure 4. Different inoculation amounts have an effect on the activity of LP69 cellenvelope protease and the growth of LP69. As the inoculation amount increased, the enzyme activity and specific activity first increased and then decreased, and the maximum was achieved at 5\%. The values were $21.78 \mathrm{U} / \mathrm{mL}$ and $1.02 \mathrm{U} / \mathrm{mg}$, and the protein content increased first with the increase of the inoculation amount, remained stable at 3\% and $5 \%$, and then began to decrease, and the OD value and $\mathrm{pH}$ value reached the highest value at $5 \%$. When the inoculation amount was $7 \%$ and $9 \%$, because the inoculation amount was too large, the bacteria grew in large amounts in the early stage, the accumulation of harmful metabolites and the rapid decrease of $\mathrm{pH}$ inhibited the growth of the bacteria.
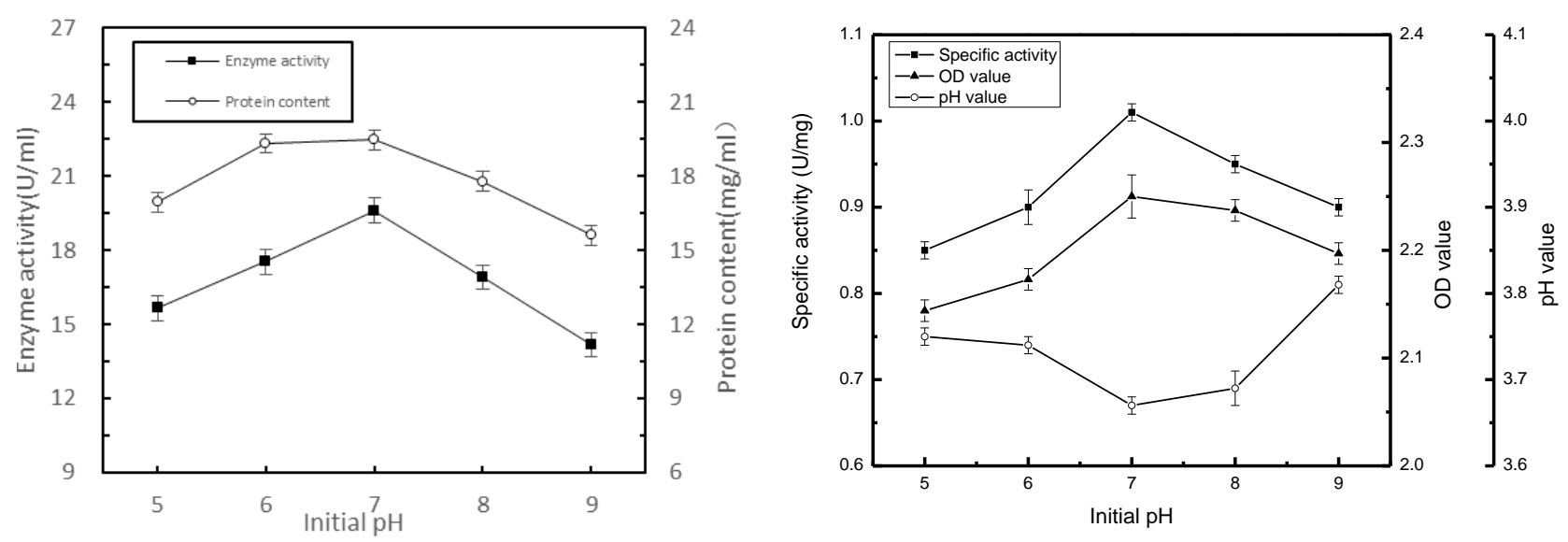

Figure 3. The effect of initial $\mathrm{pH}$ on CEP produced by Lactobacillus plantarum LP69 

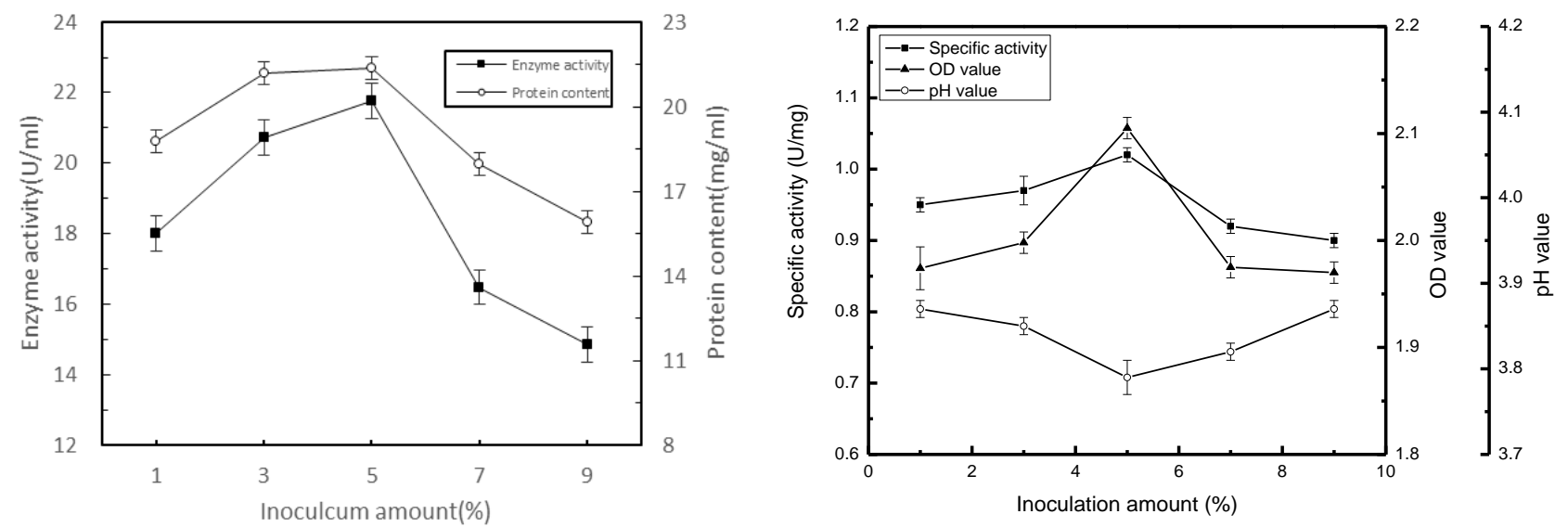

Figure 4. The effect of inoculation amount on CEP produced by Lactobacillus plantarum LP69

On the other hand, the prophase concentration of the bacteria was too high, the substrate was consumed too fast, and the bacteria were prone to senescence, so high inoculum was not beneficial to the growth and reproduction of the bacteria. Therefore, based on the test results, the optimal inoculation amount was $5 \%$.

\section{Orthogonal design to optimize CEP fermentation conditions}

The single factor experiment screened out the optimal time of $20 \mathrm{~h}$, temperature of $37^{\circ} \mathrm{C}$, initial $\mathrm{pH}$ of 7 and inoculation amount of 5\%. The orthogonal design of four factors and three levels was selected to further investigate the influence of four factors on enzyme activity, protein content and specific activity. According to the single factor test result, the factor level of the orthogonal test is obtained in Table 1, and the design and results of the orthogonal test are shown in Table 2.

According to the magnitude of the range $R$, the primary and secondary factors were arranged. The larger $\mathrm{R}$ is, the more important this factor is in the experiment. Conversely, the smaller $\mathrm{R}$ is, the less important this factor is. When the enzyme activity was used as an index, after the factors were ranked by the magnitude of the $\mathrm{R}$ value, the table shows that time has the greatest influence on enzyme activity, followed by $\mathrm{pH}$, then temperature, and finally inoculation amount. In addition, the $\mathrm{K}$ value shows that when enzyme activity is used as an index, the best level combination is $\mathrm{A}_{2} \mathrm{~B}_{1} \mathrm{C}_{2} \mathrm{D}_{2}$. When protein content was used as an indicator, the order of the major and minor factors arranged by the $\mathrm{R}$ value was: time> temperature $>$ inoculation amount $>\mathrm{pH}$ value. Observing the data in Table 2, we can see that the best level combination is $A_{2} B_{1} C_{3} D_{3}$ when the protein content is used as an indicator. When the specific activity was used as an indicator, the factors were arranged in order of priority according to their $\mathrm{R}$ value: temperature has the greatest influence on activity, followed by initial $\mathrm{pH}$ value, and finally inoculation amount and time. From the table, we can see: this experiment When the specific activity is used as an indicator, the best level combination is $\mathrm{A}_{3} \mathrm{~B}_{3} \mathrm{C}_{1} \mathrm{D}_{2}$.

Combining the above three indicators, since the specific activity value was computed by dividing the enzyme activity by the protein content, its value could better represent the activity of the cellenvelope protease, so the specific activity was selected as an important reference. Therefore, the best level combination for this experiment was selected as $A_{3} B_{3} C_{1} D_{2}$, that was, the time was $22 h$, the temperature was $39^{\circ} \mathrm{C}$, the initial $\mathrm{pH}$ value was 6 , and the inoculation amount was $5 \%$. Under this culture condition, the target protease activity of LP69 reached $22.31 \pm 0.82 \mathrm{U} / \mathrm{mL}$, the protein content was $19.07 \pm 0.36 \mathrm{mg} / \mathrm{mL}$, and the specific activity was $1.17 \pm 0.06 \mathrm{U} / \mathrm{mg}$. After the optimized medium, the enzyme activity increased by $3.8 \%$, and the specific activity increased by $15.8 \%$.

Ren et al.(2014) determined the optimal fermentation conditions for cell-envelope protease production by $L$. acidophilus JQ-1 through single factor and response surface experiments: initial $\mathrm{pH}$ value 8.0, fermentation temperature $37^{\circ} \mathrm{C}$, and fermentation time 20h. Zhang et al. (2016) found through orthogonal experiments that the optimal fermentation conditions for cell-envelope protease production by Lactobacillus helveticus ATCC15019 were: initial $\mathrm{pH}$ value 7.4, fermentation temperature $37^{\circ} \mathrm{C}$, and fermentation time $20 \mathrm{~h}$. This is slightly different from the results of this test, which may be caused by different strains. 
Table 1. The factors and levels of orthogonal experiment of LP69 producing CEP culture conditions

\begin{tabular}{ccccc}
\hline Factor level & Time $(\mathrm{h})$ & Temperature $\left({ }^{\circ} \mathrm{C}\right)$ & Initial $\mathrm{pH}$ & $\begin{array}{c}\text { Inoculation } \\
\text { amount }(\%)\end{array}$ \\
\hline 1 & 18 & 35 & 6 & 3 \\
2 & 20 & 37 & 7 & 5 \\
3 & 22 & 39 & 8 & 7 \\
\hline
\end{tabular}

Table 2. The design and results of orthogonal experiment of LP69 producing CEP culture conditions

\begin{tabular}{|c|c|c|c|c|c|c|c|c|c|}
\hline Run & A & B & $\mathrm{C}$ & $\mathrm{D}$ & R1 ※ & $\mathrm{R} 2$ & R3 & OD & $\mathrm{pH}$ \\
\hline 1 & 18 & 35 & 6 & 3 & 15.00 & 10.85 & 1.38 & 2.699 & 3.81 \\
\hline 2 & 18 & 37 & 7 & 5 & 19.14 & 6.72 & 2.85 & 2.764 & 3.88 \\
\hline 3 & 18 & 39 & 8 & 7 & 11.05 & 21.52 & 1.51 & 2.74 & 3.98 \\
\hline 4 & 20 & 35 & 7 & 7 & 23.66 & 28.58 & 0.83 & 2.851 & 3.86 \\
\hline 5 & 20 & 37 & 8 & 3 & 14.44 & 16.53 & 0.87 & 2.85 & 3.95 \\
\hline 6 & 20 & 39 & 6 & 5 & 17.07 & 14.48 & 3.81 & 2.795 & 3.73 \\
\hline 7 & 22 & 35 & 8 & 5 & 15.85 & 16.70 & 1.95 & 2.732 & 3.98 \\
\hline 8 & 22 & 37 & 6 & 7 & 16.32 & 6.89 & 2.37 & 2.756 & 3.71 \\
\hline \multirow[t]{4}{*}{9} & 22 & 39 & 7 & 3 & 15.76 & 6.38 & 2.47 & 2.781 & 3.83 \\
\hline & $\mathrm{K}_{1}$ & 45.19 & 54.51 & 48.39 & 45.2 & & & & \\
\hline & $\mathrm{K}_{2}$ & 55.17 & 49.9 & 58.56 & 52.06 & & & & \\
\hline & $\mathrm{K}_{3}$ & 47.93 & 43.88 & 41.34 & 51.03 & & & & \\
\hline \multirow[t]{7}{*}{$\mathrm{R}_{1}$} & $\mathrm{k}_{1}$ & 11.30 & 18.17 & 16.13 & 15.07 & & & & \\
\hline & $\mathrm{k}_{2}$ & 18.39 & 16.63 & 19.52 & 17.35 & & & & \\
\hline & $\mathrm{k}_{3}$ & 15.98 & 14.63 & 13.78 & 17.01 & & & & \\
\hline & $\mathrm{R}$ & 7.09 & 3.54 & 5.74 & 2.28 & & & & \\
\hline & $\mathrm{K}_{1}$ & 39.09 & 56.13 & 32.22 & 33.76 & & & & \\
\hline & $\mathrm{K}_{2}$ & 59.59 & 30.14 & 41.68 & 37.9 & & & & \\
\hline & $\mathrm{K}_{3}$ & 29.97 & 42.38 & 54.75 & 56.99 & & & & \\
\hline \multirow[t]{7}{*}{$\mathrm{R}_{2}$} & $\mathrm{k}_{1}$ & 13.03 & 18.71 & 10.74 & 11.25 & & & & \\
\hline & $\mathrm{k}_{2}$ & 19.86 & 10.05 & 13.89 & 12.63 & & & & \\
\hline & $\mathrm{k}_{3}$ & 9.99 & 14.13 & 18.25 & 19.01 & & & & \\
\hline & $\mathrm{R}$ & 9.87 & 8.66 & 7.51 & 7.76 & & & & \\
\hline & $\mathrm{K}_{1}$ & 5.74 & 4.16 & 7.56 & 4.72 & & & & \\
\hline & $\mathrm{K}_{2}$ & 5.51 & 6.09 & 6.15 & 8.61 & & & & \\
\hline & $\mathrm{K}_{3}$ & 6.79 & 7.79 & 4.33 & 4.71 & & & & \\
\hline \multirow[t]{4}{*}{$\mathrm{R}_{3}$} & $\mathrm{k}_{1}$ & 1.91 & 1.39 & 2.52 & 1.57 & & & & \\
\hline & $\mathrm{k}_{2}$ & 1.83 & 2.03 & 2.05 & 2.87 & & & & \\
\hline & $\mathrm{k}_{3}$ & 2.26 & 3.01 & 1.44 & 1.57 & & & & \\
\hline & $\mathrm{R}$ & 0.43 & 1.62 & 1.08 & 1.3 & & & & \\
\hline
\end{tabular}

A,Time (h);B,Temperature $\left({ }^{\circ} \mathrm{C}\right) ; \mathrm{C}$,Initial pH;D,Inoculation amount $(\%) ; ※$ Enzyme activity, U/mL; Protein content , $\mathrm{mg} / \mathrm{mL}$; Specific activity, U/mg; Ki is the sum of experimental indicators corresponding to level $\mathrm{i}$; ki is the average value of $\mathrm{Ki}$; R,range

\section{CONCLUSIONS}

Through the single factor test, the optimal time was selected for $20 \mathrm{~h}$, the optimal temperature was $37^{\circ} \mathrm{C}$, the initial $\mathrm{pH}$ was 7 , and the optimal inoculation amount was 5\%. Comprehensive consideration of enzyme activity, enzyme content and specific activity, and finally selected specific activity as an important indicator. Temperature has the greatest effect on specific activity, followed by initial $\mathrm{pH}$, and finally inoculation amount and time. So the best combination obtained is $22 \mathrm{~h}$, temperature $39^{\circ} \mathrm{C}$, 
initial $\mathrm{pH}$ value of 6 , and inoculation amount of $5 \%$. The obtained CEP enzyme activity of LP69 reached $22.31 \pm 0.82 \mathrm{U} / \mathrm{mL}$, the protein content was $19.07 \pm 0.36 \mathrm{mg} / \mathrm{mL}$, and the specific activity was
$1.17 \pm 0.06 \mathrm{U} / \mathrm{mg}$, which provided some references for the future applications of cell-envelope proteases.

\section{ACKNOWLEDGMENTS}

This work was partially backed by the Key Research and Development Program of Shaanxi (Program No.2019ZDLNY06-03).

\section{REFERENCES}

1. Agyei, D.\&Danquah, M.K.(2010).In-depth characterization of Lactobacillus delbrueckii subsp. lactis 313 for growth and cell-envelope-associated proteinase production. Biochem Eng J, 64,61-68.

2. Agyei, D.\&He, L.Z. (2015). Evaluation of cross-linked enzyme aggregates of lactobacillus cell-envelope proteinases, for protein degradation. Food and Bioproducts Processing, 94, 59-69.

3. Bradford, M. M. (1976). A rapid and sensitive method for the quantitation of microgram quantities of protein utilizing the principle of protein-dye binding.Analytical Biochemistry,72,248-254.DOI: 10.1016/0003-2697(76)90527-3.

4. Chen, H., Huang, J., Cao, B. Y., Chen, L., Song, N. (2018). Study of extraction and enzymatic properties of cell-envelope proteinases from a novel wild Lactobacillus plantarum LP69. Catalysts, 8(8), 325. DOI: $10.3390 /$ catal 8080325 .

5. Chen, H., Hui, Y.X., Chen, L., Wan, H.C., Shu, G.W. \& Li, H. (2015). Effect of probiotic Lactobacillus strains on Antioxidant activity from fermented goat milk. Carpathian Journal of Food Science and Technology, 7(2), 109-114.

6. Chen, H., Ji, Z., Shu, G.W. \& Xing, H. (2012). Effect of probiotic Lactobacillus strains on Angiotensin-I converting enzyme inhibitory activity from fermented goat milk. Adv. Mater. Res,531, 442-445. DOI: 10.4028/www.scientific.net/AMR.531.442.

7. Christos, G., Papadimitriou. \&Anna,V. (2007) .Identification of peptides in traditional and probiotic sheep milk yoghurt with angiotensin I-converting enzyme (ACE) -inhibitory activity.Food Chemistry, 4,1-10.

8. Espeche,T.M.B.,Savoy, d.G. G.\&Hebert, E. M.(2009). Release of the cell-envelope-associated proteinase of Lactobacillus delbrueckii subspecies lactis CRL 581 is dependent upon $\mathrm{pH}$ and temperature. Journal of agricultural and food chemistry, 57(18), 8607-8611. DOI: 10.1021/jf901531q.

9. Evivie,S.E., Huo,G.C.\& Igene,J.O. (2017).Some current applications, limitations and future perspectives of lactic acid bacteria as probiotics. Food \& Nutrition Research,61(1),1318034. DOI: 10.1080/16546628.2017.1318034.

10. Georgieva, R., Iliev, I.\&Haertle,T.(2009).Technological properties of candidate probiotic Lactobacillus plantarum strains[J]. International Dairy Journal, 19(11), 696-702.

11. Laloi, P., Atlan, D., Blanc, B., Gilbert, C., Portalier, R. (1991). Cell-wall-associated proteinase of Lactobacillus delbrueckii subsp. bulgaricus CNRZ 397: differential extraction, purification and properties of the enzyme.Appl. Microbiol. Biotechnol., 36, 196-204. DOI: 10.1007/BF00164419

12. Liu, S.N., Ye,H.\&Zhou,Z.J.(2011).Lactic acid bacteria in traditional fermented Chinese foods.Food Research International, 44(3),643-651.

13. Ngo, L. T. A., Pham, T. L.\&Le, V. V. M. (2008). Purification of endopolygalacturonase from submerged culture of Aspergillus awamori L1 using a two-step procedure: Enzyme precipitation and gel filtration. Int. Food Res. J., 15, 135-140.

14. Pang, F.P.\&Huo,N.R.(2017).Optimization of Protease-producing Culture Conditions of Lactobacillus helveticus by Response Surface Methodology.China Condiment, 42 (4) , 4-8.

15. Ren X.F. (2014). Isolation and purification of the cell wall protease from Lactobacillus acidophilus JQ-1 and its hydrolysis of casein to produce ACE inhibitory peptides. Ningbo,Ningbo University.

16. Ren, X. F., Pan, D. D., Zeng, X. Q., Zhao, Z. W. \&Zhu, D. D.(2014). Optimization of culture conditions and fermentation conditions for Cell Wall Proteinase (CEP) production by Lactobacillus acidophilus. Journal of Chinese Institute of Food Science and Technology, 14(2), 146-153.

17. Rolfe, R.D. (2000). The role of probiotic cultures in the control of gastrointestinal health. The Journal of 
nutrition, 130(2S Suppl.), 396S-402S. DOI: 10.1093/jn/130.2. 396S.

18. Roobab,U., Batool,Z.\&Manzoor,M.F.(2020). Sources, formulations, advanced delivery and health benefits of probiotics. Current Opinion in Food Science, 32,17-28. DOI: 10.1016/j.cofs.2020.01.003.

19. Samartsev, A. A., Astapovich, N. I.\&Novik, G. I. (2000). Production of cell-wall-bound proteinases in Bifidobacterium adolescentis 94-BIM. Microbiology, 69(6), 655-658. Doi:10.1023/A:1026697906562.

20. Scolari, G., Vescovo, M., Zacconi, C. \&Vescovi, F. (2006). Extraction and partial characterization of proteolytic activities from the cell surface of Lactobacillus helveticus Zuc2. Journal of Dairy Science, 89(10), 3800-3809. DOI: 10.3168/jds.S0022-0302(06)72421-3.

21. Shu, G.W., Lei, N., Chen, H., Hu, M. \& Yang, H. (2016). Application of central composite design to optimize the amount of carbon source and prebiotics for Bifidobacterium bifidum BB01. Acta Universitatis Cibiniensis. Series E: Food Technology, 20(1), 41-52. DOI:10.1515/aucft-2016-0003

22. Siezen,R.J., Tzeneva,V.A.\&Castioni,A. (2019) .Phenotypic and genomic diversity of Lactobacillus plantarum strains isolated from various. Environmental Microbiology, 12(2010),758-773.

23. Tatsuya, U., Jung-Hye, C. \&Hor-Gil, H. (2015). Changes in human gut microbiota influenced by probiotic fermented milk ingestion. Journal Dairy Science, 98(6), 3568-3576.DOI: 10.3168/jds.20148943.

24. Widyastuti,Y. \&Febrisiantosa,A. (2014) .The role of lactic acid bacteria in milk fermentation.Food and Nutrition Sciences, 5(4),435-442.

25. Zhang C.Y.\&Pan D.D. (2016). Study on the culture and extraction conditions of the protease produced by Lactobacillus helveticus. Food Science, 27(10),416-419.

26. Zhao, Y., Hong, K.\&Zhao,J.X.(2019). Lactobacillus fermentum and its potential immunomodulatory properties. Journal of Functional Foods, 56,21-32. DOI: 10.1016/B978-0-12-374407-4.00265-X. 